\title{
HIERATIC WINE JAR DOCKETS FROM TUTHMOSIS'S IV TEMPLE IN GURNA
}

\author{
Mohamed NASSAR ${ }^{1}$ and Maher EISSA ${ }^{2}$ \\ ${ }^{1}$ Faculty of Archaeology, Fayoum University, Egypt \\ E-mail: man00@,fayoum.edu.eg \\ ${ }^{2}$ Faculty of Archaeology, Fayoum University, Egypt \\ E-mail: Maher.Eissa@,fayoum.edu.eg
}

\begin{abstract}
This paper deals with the texts on a collection of hieratic wine jar dockets written in black ink. These dockets are now in the National Museum for Egyptian Civilization at Cairo, and they were excavated by E. Bresciani in the 1970s at Tuthmosis's IV temple in Gurna - Thebes. According to the paleography, formulae and content, the dockets date to the $18^{\text {th }}$ dynasty, and the beginning of $19^{\text {th }}$ dynasty, and they are comparable with similar dockets from Malkata.
\end{abstract}

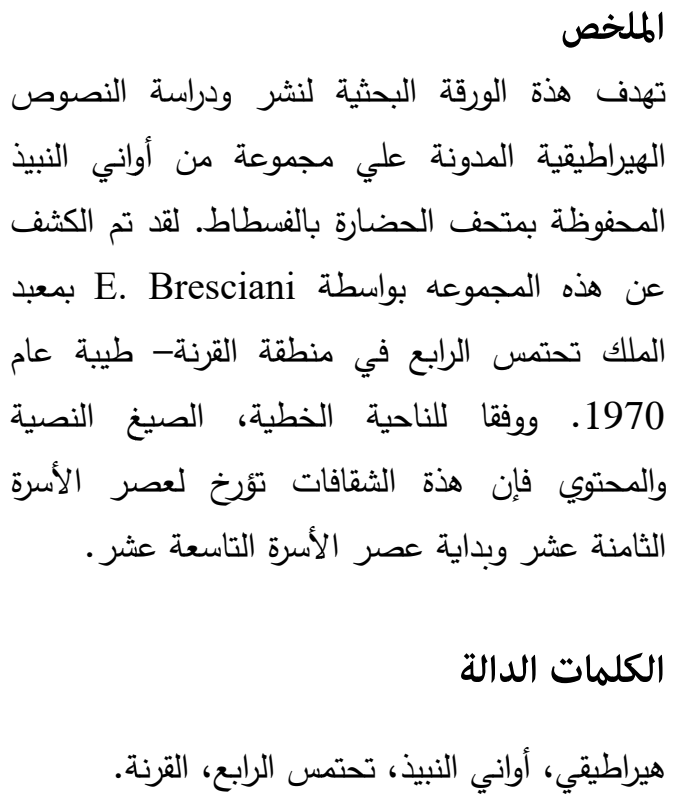

Hieratic; Wine Jar Dockets; Tuthmosis IV; Gurna.

\section{KEYWORDS}

هيراطيقي، أواني النبيذ، تحتمس الرابع، القرنة.

\section{INTRODUCTION}

The present paper deals with a group of hieratic dockets, stored in the National Museum for Egyptian Civilization (NMEC). ${ }^{1}$ The Pisa University expedition led by E. Bresciani in the 1970s at Tuthmosis's IV temple in Gurna -Thebes have uncovered

We would like to express our gratitude to Dr. Rob Demarée for his revision of the paper and made valuable comments.

${ }^{1}$ For more information and details about the NMEC and its collection, see EISSA, $C d E$ 89 (2014), 197201. 
collection of hieratic ostraca and dockets. ${ }^{1}$ Their topics can be divided into three groups: the first one (Nos. 332, 341, 429, 434, 436, 437) consists of wine jar dockets, which will be dealt with in this article, the second group (Nos. 339, 343, 348, 452) contains parts of private letters, and the third group (Nos. 342, 406, 409, 449) has lists of titles, names of workmen and deliveries. The second and the third group will be published in separate articles.

These dockets are written in black ink only and on one side of the sherds. It is characterize by fixed formula. The dockets regularly include of five classes of formula or expressions : date, the type of wine, the delivering institution, the place of wine, title and personal name of the vineyard. Studies on the dockets from the temple of Tuthmosis's IV, by comparison with those from other sites, suggest that these dockets record the supplies of wine relating to the temple. and provide interesting information about the locations of winemaking.

\section{NMEC No. 437 (Fig 1, 1a)}

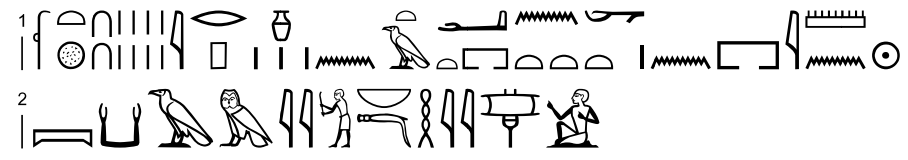

\section{Transliteration:}

1- rnpt sp 28 irp $^{(\mathrm{a})} n t 3^{\mathrm{C}} \mathrm{t} n t \mathrm{~h}$ ht $n$ pr imn $\mathrm{r}^{(\mathrm{b})}$

2- hry k3mw $n b-m h y t^{(\mathrm{c})}$

\section{Commentary}

- Dimension: $10 \mathrm{~cm}$ x $6.5 \mathrm{~cm}$.

- Material: Pottery.

- Dating: $18^{\text {th }}$ Dynasty.

- Condition\& Description: the fragment is in a good condition and in two parts, and it is inscribed on one side with two lines in black ink.

(a) $\mathcal{Z}:$ the determinative of $\operatorname{irp}$ stands for $\stackrel{\Theta}{1}$ । rather than $\Theta$, which appeared also on D. NMEC No. 341 in line 2. The following table shows that the writing is slightly different from its ordinary shape W22+Z1.

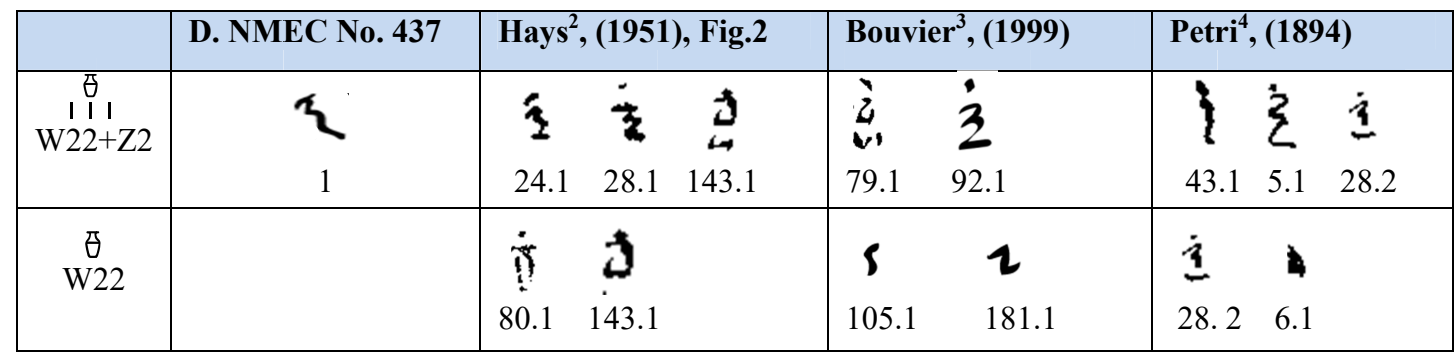

Table. 1 The differences between of W22 and W22+Z2

${ }^{1}$ For the history and more information about excavations and archaeological projects of the University of Pisa in the area of the Thutmosis temple, see: Bresciani, EVO 4 (1981), 1-40; Bresciani, CNR, Vol. 1, 393-411; Guidotti. EVO 18 (1995), 23-29; Guidotti, EVO 10.1 (1987), 21-34; Guidotti, EVO 12 (1989), 55-77; Marzoni Fecia di Cossatom \& Ronca, , EVO 16 (1993), 73-85; www.egittologia:unipi.it.

${ }^{2}$ Hayes, JNES 10(1), (1951), 35- 56, fig. 2- 3.

${ }^{3}$ Bouvier, Catalogue des etiquettes de jarres hieratiques inedites de l' institut d' Egyptologie de Strasbourg, Fascicule I (1-535), DFIFAO 35, P1.7.28.

${ }^{4}$ Petrie, Tell el Amarna, pl. XXII.5. 
(b) $0^{\prime \prime}<\square^{\prime \prime}:$ It is not clear to me but may represent $\odot$.

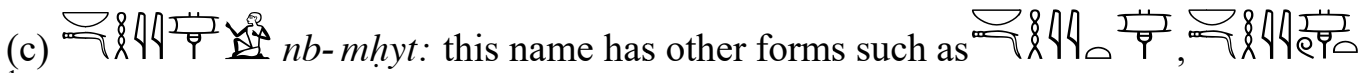
${ }^{1}$. It occurs once on a docket from Tell- Amarna dated to the reign of the king Akhenaton. ${ }^{2}$ It may be the same person who lived in the end of reign of Amenhotep III, and then moved with Akhenaton to Tell- Amarna.

\section{NMEC No. 332 (Fig 2, 2a)}

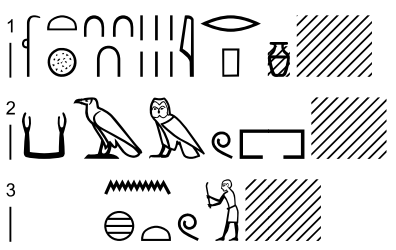

\section{Transliteration}

1- rnpt $s p^{(\mathrm{a})} 36^{(\mathrm{b})}$ irp .....

2- $k 3 m w$

3- $n h t w{ }^{(\mathrm{c})} \ldots .$.

\section{Translation}

1- Regnal year 36, wine ......

2- vineyard ........

3- nhtw ........

\section{Commentary}

- Dimension: $12 \mathrm{~cm}$ x $9 \mathrm{~cm}$.

- Material: Pottery.

- Dating: $18^{\text {th }}$ Dynasty

- Condition\& Description: the fragment is in good condition and in two parts, inscribed on one side with three lines in black ink.

(a) rnpt sp 36: this docket refers to (year 36) the highest date of Amenhotep III in this collection. The same date is found on dockets from Deir el-Medineh ${ }^{3}$, whilst jars from his tomb attest year $37,{ }^{4}$ and jars from his palace at Malkata mention year $38 .{ }^{5}$ Černý suggested that Amenophis III lived at least into the thirty-ninth year of his reign according to Amarna table in the British Museum, which may be dating to year $39 .{ }^{6}$ While Hornung suggest at least 37 and perhaps 38 years should be assumed for Amenhotep III $^{7}$.

(b) $\mathcal{Y}$ : It represents a different form of the number 30 , where the standard form would bey $y-8$.

(c) L/ : Perhaps represents part of the name of the chief of the vineyard being $n h t w$. His name is attested on a docket from Dier el Madina dated to the same period. ${ }^{9}$ period. ${ }^{9} \mathrm{He}$ is also attested on O. Cairo JE 62312 as a chief of the vineyard. ${ }^{10}$

\footnotetext{
${ }^{1}$ Ranke, PN I, 185.7.

${ }^{2}$ Petrie, Tell el Amarna, pl. XXII.5., Wahlberg, The Wine Jars Speak A text study, 95.

${ }^{3}$ Koenig, Catalogue des etiquettes des jarres hiératiques de Deir el-Medineh, II, pls. 41.

${ }^{4}$ Kondo, Orient 26, (1989), 94-9., Aston, ÄL Vol. 22/23, (2012/2013), 293.

${ }^{5}$ Hayes, JNES 10, 1951, 56, fig

${ }^{6}$ Černý, JEA 50, (1964), 37.

${ }^{7}$ Hornung; Rolf; David and Marianne, Ancient Egyptian Chronology, HDO 38, 205.

${ }^{8}$ Möller, Hieratische Paläographie II, 525.

${ }^{9}$ Koenig, Catalogue des étiquettes des jarres hiératiques de Deir el-Medineh, II, Pl. 38.

${ }^{10}$ Černý, Tut ${ }^{c} a n k h a m \bar{n}$ 's Tomb Series II. Hieratic Inscriptions from the Tomb of Tut ${ }^{c}$ ankhamūn, 22, No. 10 .
} 


\section{NMEC No. 341 (Fig 3, 3a)}

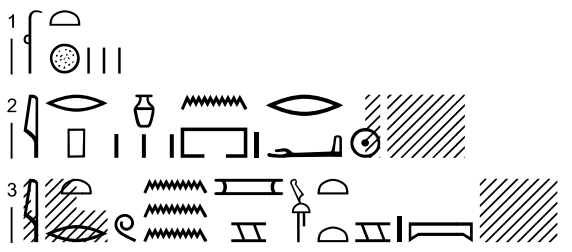

\section{Transliteration}

1- rnpt sp 3

2- irp $n$ pr $r^{(\mathrm{a}) \ldots \ldots . . .}$

3- ... itrw imntt ${ }^{(\mathrm{b})(\mathrm{c})} \quad h r y[k 3 m w]^{(\mathrm{d}) \ldots}$

\section{Translation}

1- Regnal Year 3

2-wine of the estate of Ra....

$3-.$. of the Western River, chief of the vineyard ...

\section{Commentary}

- Dimension: $11 \mathrm{~cm}$ x $11 \mathrm{~cm}$.

- Material: Pottery.

- Dating: $18^{\text {th }}$ Dynasty

- Condition\& Description: the fragment is in a good condition and in two parts, and it is inscribed on one side with three lines in black ink.

(a) 2Shis word appears with the same form in O.AM 50 Jahy ${ }^{1}$ transcribe it as 通, but perhaps it represents $\odot$ rather than the $18^{\text {th }}$ Dynasty appears with the same form, ${ }^{2}$ in addition to the determinative of the word which represent $\odot{ }^{3}$

(b) itrw imntt: Many wine jar dockets contain this term. The word is a topographical term which refers to a location in the north-western Nile Delta region ${ }^{4}$, this is thought

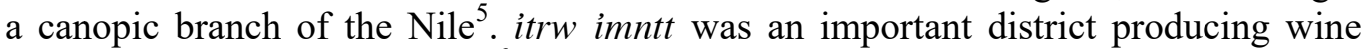
until the Greco- Roman period. ${ }^{6}$

(c) 3 : This sign appeared with the same form during the Ramasside period to represent more than $\frac{0_{0}}{\mathbb{P}_{7}}$.

(d) According to the form of the title chief of the vineyard, we can complete the gap with $k 3 m w .{ }^{8}$ The end of this line is lost so the name of the vineyard remains unknown. unknown.

\footnotetext{
${ }^{1}$ Leahy, The Hieratic labels, 1979-1982. Amarna Reports II, 91, figure 6.8, 50.

${ }^{2}$ Möller, Hieratische Paläographie II, Anhang XXI.

${ }^{3}$ Möller, Hieratische Paläographie II, 303.

${ }^{4}$ McGovern, JEA 83, (1997), 72.

${ }^{5}$ Poo, Wine \& Wine Offering In The Religion Of Ancient Egypt, 30, 15.

${ }^{6}$ Murray, 'Viticulture and wine production,' in: Nicholson, P\& Shaw, I., Ancient Egyptian Materials and Technology, 597.

${ }^{7}$ Wimmer, Hieratische Paläographie der nichtliterarischen Ostraka der 19. und 20. Dynastie,vol. 2, 257.

${ }^{8}$ Petrie, Tell el Amarna, pl. XXIII.
} 


\section{NMEC No. 434 (Fig 4, 4a)}

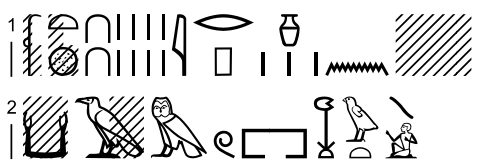

\section{Transliteration}

1- [rnpt sp] $28^{(\mathrm{a})} \operatorname{irp} n \ldots . .{ }^{(\mathrm{b})}$

2- $[k 3] m w^{(\mathrm{c})} h 3 w t^{(\mathrm{d})}$

\section{Translation}

1- [Regnal year] 28, wine of .....

2- Vineyard $h 3 w t . . .$.

\section{Commentary}

- Dimension: $15 \mathrm{~cm} \times 16 \mathrm{~cm}$

- Material: Pottery.

- Dating: $18^{\text {th }}$ Dynasty.

- Condition\& Description: The fragment is in a good condition, in two parts, inscribed on one side with two lines in black ink.

(a) 9 : represents a part of the dating formula rnpt sp.

(b) According to the wine jar dockets formulae, irp is followed by the name of the estate, but the left part hasn't any trace of writing so I don't think the left part is part of this vase.

(c) $(0)\}^{\mathcal{Y}}$ : this group represent a part of the word [k3]mw as it appears with the same form in Amal 132 U

(d) the had a different form as appeared with the same form in O. DeM/ $/ 3 \mathbf{L}$

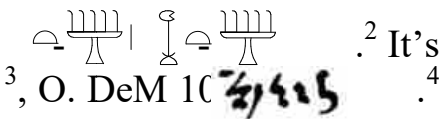
Another example of this name is found in P. Gurob dating to the reign of the king Amenhotep III. ${ }^{5}$

\section{NMEC No. 436 (Fig 5, 5a)}

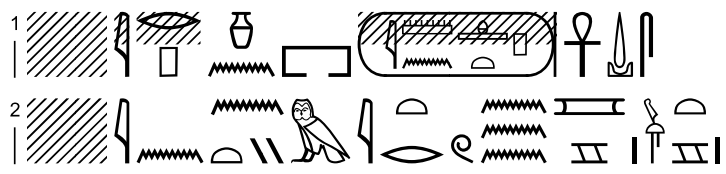

\section{Transliteration}

${ }^{[1]}[$ rnpt sp...] irp $n$ pr (imn- htp) `.w.s (a)

${ }^{[2]}$.... in nty m itrw imntt ${ }^{(b)}$
Translation

${ }^{[1]}$ [Regnal Year....], wine of the estate of Amenhotep L.P.H

${ }^{[2]}$.... by which is in the Western River

\section{Commentary}

${ }^{1}$ Petrie, Tell el Amarna, pl. XXII.5.

${ }^{2}$ Ranke, PN 1, 262-25.

${ }^{3}$ Grandet, , Catalogue des ostraca hiératiques X, Nos 10001-10123, 5 - 6.

${ }^{4}$ Grandet, Catalogue des ostraca hiératiques X, 7- 8, 184; Hagen, JEA 96, (2010), 71-82.

${ }^{5}$ Griffith, Hieratic Papayri from Kahun and Gurob, Pl. XXXIX,11. 
- Dimension: $14 \mathrm{~cm}$ x $6 \mathrm{~cm}$

- Material: Pottery.

- Dating: it can date to the $18-19^{\text {th }}$ dynasty.

- Condition\& Description: the fragment is in a good condition, in two parts, and it is inscribed on one side with two lines in black ink..

(a) 111$)$ ) $35 \leq p) \quad$ : The text is not clear, we suggest reconstruction as (l)

(b) : According to the remaining traces, we can complete the word as hose

\section{NMEC No. 429 (Fig 6, 6a)}

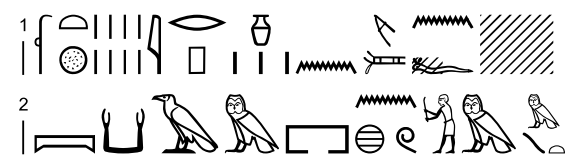

\section{Transliteration}

${ }^{[1]}$ rnpt sp 8 irp $n \mathrm{mr} \mathrm{tm}^{\text {(a) }}$ n.f?.......

${ }^{[2]}$ hry $k 3 m w$ nhw $m m w t^{\left({ }^{(b)}\right.}$

\section{Translation}

${ }^{[1]}$ Regnal Year 8, wine of $\mathrm{mr} t m$

$n . f ? \ldots . . .$.

${ }^{[2]}$ The chief of vineyard $n h w m m w t$

\section{Commentary}

- Dimension: $8 \mathrm{~cm}$ x $9 \mathrm{~cm}$.

- Material: Pottery.

- Dating: probably $18-19^{\text {th }}$ dynasty.

- Condition\& Description: the fragment is in a good condition, in two parts, and it is inscribed on one side with two lines in black ink.

(a) $\mathrm{Nr}$ tm: Meidum is one of the most frequently mentioned place of winemaking, this place does not appear in the wine jar dockets from Amarna ${ }^{1}$ or Malkata dockets ${ }^{2}$, but it is found on some wine jar dockets from Deir el Medina. ${ }^{3}$

(b) $\ominus$ e ○ e ${ }^{4}$. This name does not appear in Malkata dockets ${ }^{5}$.

\section{Wine jars form and formula}

The texts of the wine jar dockets follow a general pattern with only minor variations. In their most elaborate form they consist of five elements: a date, the type of the wine,

\footnotetext{
${ }^{1}$ Wahlberg, The Wine Jars Speak A text study, 60.

${ }^{2}$ Hayes, JNES 10 No.2, (1951),35-56.

${ }^{3}$ O. DeM. 6320, 6322=Koenig, Catalogue des étiquettes des jarres hiératiques de Deir el-Medineh, II, pl. 38.

${ }^{4}$ Ranke, PN I, 185.7.

${ }^{5}$ Hayes, JNES 10 No.2, 35-56.
} 
the delivering institution, the place of wine production and the name of the chief of the vineyard. ${ }^{1}$

\begin{tabular}{|l|c|c|}
\hline The first line & $\begin{array}{c}(1) \\
\text { Dating formula } \\
(\text { rnpt } s p \mathrm{x})\end{array}$ & $\begin{array}{c}\text { (2) } \\
\text { The type of wine and the } \\
\text { institution } \\
(\text { irp } n \mathrm{x})\end{array}$ \\
\hline The second line & \multicolumn{2}{|c|}{$\begin{array}{c}\text { (3) } \\
(\text { itrw } \text { imnt })\end{array}$} \\
\hline $\begin{array}{l}\text { The second or } \\
\text { third line }\end{array}$ & $\begin{array}{c}\text { (4) } \\
\text { The place of wine } \\
\text { production }\end{array}$ & $\begin{array}{l}\text { The name of the chief of } \\
\text { the vineyard } \\
(h r y k 3 m w)\end{array}$ \\
\hline
\end{tabular}

Table.2 General form of wine jar docket

Dating formula: It represents the first element of the text. The normal form of the formula is rnpt $s p$ + the date without the season, month or the name of the king. ${ }^{2}$

The place of production of the wine: the text refers to vineyards and the place of production that the wine was intended for it. The scribe used three forms 1) irp $n p r+$ the place "wine of the estate of + the place". 2) irp $n$ t3 't $n t t h t+p r+$ the place "a wine of the orchard of the estate of + the place". 3) irp+ the place. The following table shows the shows the wine delivering institutions in the collection under study.

\begin{tabular}{|c|c|}
\hline The estate of the wine & Sources \\
\hline 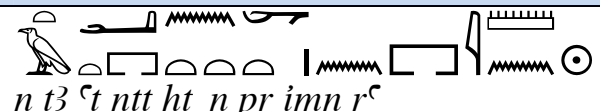 & D. NMEC No. 437 \\
\hline 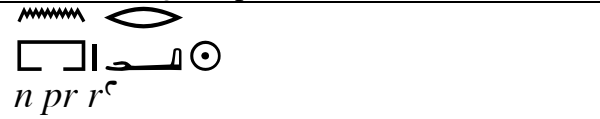 & D. NMEC No. 341 \\
\hline  & D. NMEC No. 436 \\
\hline 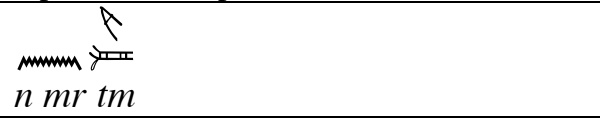 & D. NMEC No. 429 \\
\hline
\end{tabular}

Table. 3 The institution delivering the wine

Sometimes this formula followed by the formula "n itrw imntt" as D. NMEC No. 436, D. NMEC No. 441.

The title and name of the chief of the vineyard: hry $k 3 m w: k 3 m w$ is one of most common terms used in the wine jar dockets with the meaning chief of the vineyard, the gardener. ${ }^{3}$ This word first appeared in the Old Kingdom with a different form as $k 3 n w .{ }^{4}$ At the end of the Second Intermediate Period the word appears in the

${ }^{1}$ Pendlebury, The City of Akhenaten: The official quarters the Excavations at Tell El-Amarna during the seasons 1926-1927 and 1931-1936, 164.

${ }^{2}$ McGovern, JEA 83, 72. Wahlberg, E., The Wine Jars Speak A text study; Hayes, JNES 10 No.2,82.

${ }^{3} \mathrm{~Wb}, \mathrm{~V}, 106$.

${ }^{4}$ Kaplony, Die Inschriften der ägyptischen Frühzeit, 1135. 
new form $k 3 m w .{ }^{1}$ During the New Kingdom, this word appears in different forms written as: $\mathbb{E}\left[\begin{array}{l}2 \\ 2\end{array}\right.$

The wine jar dockets shows several titles for both a superior and a subordinate of the wine industry ${ }^{6}$. hry $k 3 m w$ is the most common title: the chief of the vineyard. This title appears with different forms as ${ }^{9}$, 14 . This title is sometimes also connected with an important title as

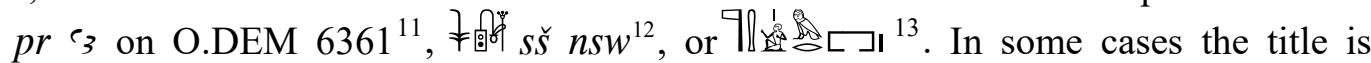
replaced by hry $b^{\top} h$ as in year 13 of Akhenaton. ${ }^{14}$

\section{Dating:}

According to the personal names and paleography, this collection can be dated to $18^{\text {th }}$ dynasty- the New Kingdom. The following table shows the comparison between the Malkata dockets and the wine jar dockets of the National Museum for Egyptian Civilization at Cairo.

\begin{tabular}{|c|c|c|c|c|}
\hline & G/M & NMEC dockets & Malkata dockets ${ }^{15}$ & $\begin{array}{c}\text { Tell el-Amarna } \\
\text { Jars }^{16}\end{array}$ \\
\hline 1 & $\bigwedge_{A 24 / 15}^{2+}$ & D. NMEC 429.2 & $\mathcal{L}$ & \\
\hline 2 & $\bigcup_{D 28 / 108}$ & $\begin{array}{lll}\text { D. NMEC } 337.2 & \text { D. NMEC } 332.2\end{array}$ & & 11 \\
\hline 3 & \}$_{M 4 / 270}$ & D. NMEC 332.1 D. NMEC 341.1 &  & 79.1 \\
\hline 4 & 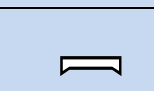 & & $\Leftrightarrow$ & \\
\hline
\end{tabular}

${ }^{1}$ Habachi, The Second Stela of Kamose and his struggle against the Hyksos Ruler and his Capital, ADAIK 8, Gluckstadt, (1972), 32.

${ }^{2}$ Habachi, The Second Stela of Kamose and his struggle against the Hyksos Ruler and his Capital, 32.

${ }^{3}$ LD IV, 37; Wahlberg, E., The Wine Jars Speak A text study, 43.

${ }^{4}$ Bouvier, Catalogue des etiquettes de jarres hieratiques inedites de l'institut d' Egyptologie de Strasbourg, P1.7.28.

${ }^{5}$ Petrie, Tell el Amarna, pl. XXII.5.

${ }^{6}$ See: Abd el-Raziq, MDAIK 35, (1979), 242.

${ }^{7}$ Koenig, Les ostraca hiératiques inédits de la bibliothèque nationale et universitaire de Strasbourg, Pl.17.58

${ }^{8}$ Hayes, JNES 10. No.1, (1951), fig.6.54.

${ }^{9} \mathrm{Koenig}$, Les ostraca hiératiques inédits de la bibliothèque nationale et universitaire de Strasbourg, Pl. Pl. 86.37

${ }^{10}$ Spiegelberg, Z̈̈S 58, (1923), 26

${ }^{11}$ Koenig, Catalogue des étiquettes des jarres hiératiques de Deir el-Medineh, II, pl. 44.

${ }^{12}$ Hayes, JNES 10. No.1, (1951), fig.6.39.

${ }^{13}$ Hayes, JNES 10. No.1, (1951), fig.7.59.

${ }^{14}$ Černý, JEA 50, (1964), 37-39., Tallet, BIFAO 95, (1995), 473.

${ }^{15}$ Hayes, JNES 10. No.1, (1951), 35-56, fig.2-3.

${ }^{16}$ Leahy The Hieratic labels, 1979-1982. Amarna Reports II. London, (1985); Griffith, F., The Jar Inscriptions, in Petrie, W (ed.), Tell el Amarna, London, (1894), Pl. XXII-XXV. 




Table.4 Wine jar dockets list of signs

Finally, this collection of dockets shows that the wine was transported to Gurna from a number of locations. Not all of the locations could be identified convincingly, but it is possible that they were located in different parts of Egypt, suggesting supplies travelling long-distance? 


\section{BIBLIOGRAPHY}

1. Abd el-Raziq, M., 'Die altägyptischen Weingärten $(k 3 n w / k 3 m w)$ bis zum Ende des Neuen Reiches,' in: MDAIK 35, (1979), 227-247.

2. Aston, D., 'Radiocarbon, Wine Jars and New Kingdom Chronology,' in: $\ddot{A} L$ Vol. 22/23, (2012/2013), 289-315.

3. Bouvier, G., Catalogue des étiquettes de jarres hiératiques inédites de l' institut d' Egyptologie de Strasbourg, Fascicule I (1-535), DFIFAO 35, Le Caire, (1999).

4. Bresciani, E., 'L'attività archeologica dell'Università di Pisa in Egitto: Fayum, Gurna, Saqqara,' in: EVO 4, (1981), 1-40.

5. ..........., 'Scavi in Egitto, 1977-1980 della Cattedra di EgittologiaUniversità di Pisa, "Quaderni de La ricerca scientifica", in: CNR, Vol. 1, Roma, (1985), 393-411.

6. Černý, J., 'Three Regnal Dates of the Eighteenth,' in: JEA 50, (1964), 37-39.

7. ......., Tut 'ankhamūn's Tomb Series II. Hieratic Inscriptions from the Tomb of Tut ${ }^{c}$ ankhamūn, Oxford: Griffith institute, (1965).

8. Eissa, M., 'A letter or an Exercise? O.NMEC107,'in: CdE 89, Fasc.117, (2014), 197-201.

9. Erman, A\& Grapow, H (ed.), Wörterbuch der Aegyptischen Sprache, 5 vols, Akademie-Verlag: Berlin (1926-1961).

10.-Grandet, P., Catalogue des ostraca hiératiques X, Nos 10001-10123, DFIFAO 46, Le Caire (2006).

11. Griffith, F., Hieratic Papyri from Kahun and Gurob, London, (1898).

12. ............. The Jar Inscriptions, in Petrie, W (ed.), Tell el Amarna, London, (1894)

13. Guidotti. M. C., 'Frammenti di contenitori in fayence dal tempio funerario di Thutmosi IV a Gurna,' in: EVO 18 (1995), 23-29.

14. ................. 'Il tempio funerario di Thutmosi IV a Gurna. La ceramica della "tomba Petrie",' in: EVO 10.1 (1987), 21-34.

15. .............., 'Il tempio funerario di Thutmosi IV a Gurna. La ceramica della “cappella superiore",' in: EVO 12 (1989), 55-77.

16. Habachi, L., The Second Stela of Kamose and his struggle against the Hyksos Ruler and his Capital, ADAIK 8, Blückstadt: J.J. Augustin, (1972).

17. Hagen, F., 'On Some Fake Hieratic Ostraca,' in: JEA 96, (2010), 71-82.

18. Hayes, W.,'Inscriptions from the Palace of Amenhotep III,' in: JNES 10 No.2, (1951),35-56.

19. ........., Inscriptions from the Palace of Amenhotep III,' in: JNES 10. No.1, (1951), 35-56.

20. Koenig, Y., Catalogue des étiquettes de jarres hiératiques de Deir el-Médineh II. Nos 6242-6497. IFAO XXI/2, Le Caire: IFAO, (1980).

21. ............ Les ostraca hiératiques inédits de la bibliothèque nationale et universitaire de Strasbourg, IFAO 33, Le Caire, (1997).

22. Kondo, J., 'Hieratic Inscriptions from the Tomb of Amenophis III,' in: Orient 26, (1989), 94-104.

23. Leahy, M. A., The Hieratic labels, 1979-1982. Amarna Reports II, London, (1985).

24. Lesko, L., A Dictionary of Late Egyptian, 2 vols, Berkeley, (1982-1990).

25. McGovern, P., 'Wine of Egypt's Golden Age: An Archaeochemical Perspective,' in: JEA 83, (1997), 69-108. 
26. Marzoni Fecia di Cossatom Y\& Ronca, F., 'Pigmenti e legante organico nei frammenti di terracotta provenienti dal tempio di Thutmosi IV (Tebe OvestEgitto), ' in: EVO 16 (1993), 73-85.

27. Möller, G., Hieratische Paläographie, II, Leipzig, (1927).

28. Murray, M., 'Viticulture and wine production,' in: Nicholson, P\& Shaw, I., Ancient Egyptian Materials and Technology, Cambridge, (2000), 577-608.

29. Pendlebury, J., The City of Akhenaten: The official quarters the Excavations at Tell El-Amarna during the seasons 1926-1927 and 1931-1936, Chapter X the inscriptions, by Fairman, Part III, London, (1951).

30. Petrie, W. M. F., Tell el Amarna, London, (1894).

31. Poo, M. C., Wine and Wine offering in the Religion of Ancient Egypt, London: Kegan, (1995).

32. Ranke, H., Die ägyptischen Personennamen, vols. I-III, Augustin: Glückstadt,(1935-1977).

33. Spiegelberg, W., 'Bemerkungen zu den hieratischen Amphoreninschriften des Ramesseums,' in: Z̈̈S 58, (1923), 25-36.

34. Tallet, P., 'Le shedeh : étude d'un procédé de vinification en Égypte ancienne,' in: BIFAO 95, (1995), 459-492.

35. Wahlberg, E., The Wine Jars Speak A text study, MA thesis, Eva-Lena Wahlberg Uppsala, (2012).

36. Wimmer, S., Hieratische Paläographie der nichtliterarischen Ostraka der 19. und 20. Dynastie, ÄAT 28, 2 vols, Wiesbaden,(1995). 


\section{Pl.1}

THE PLATES

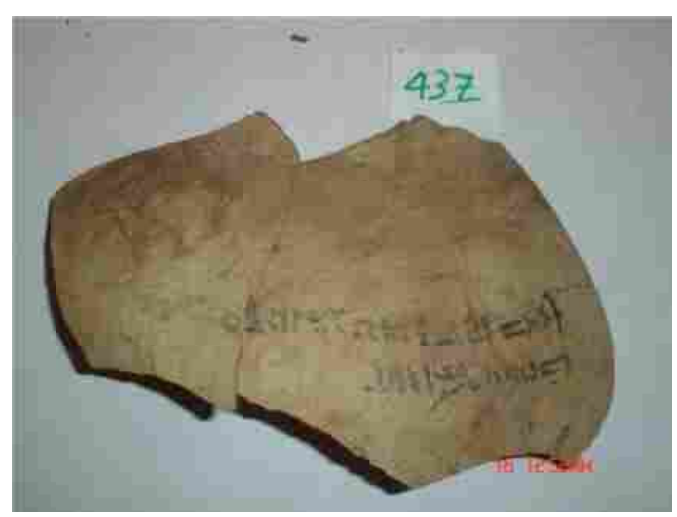

Fig 1: D. NMEC No. 437

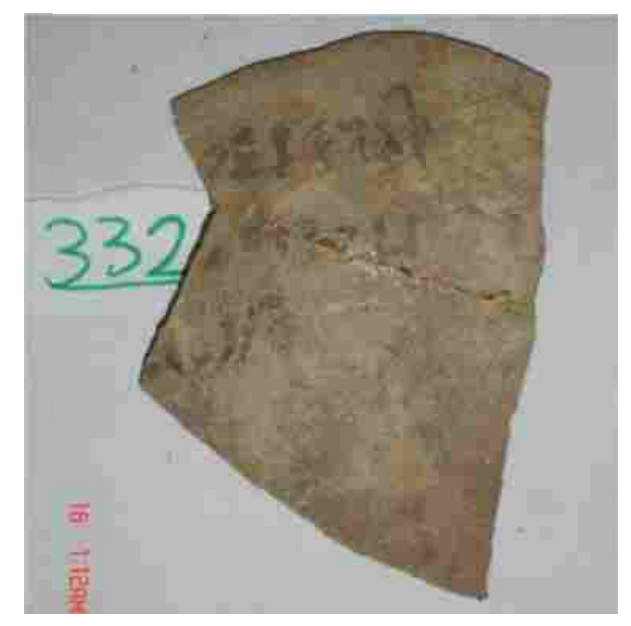

Fig 2: D. NMEC No. 332

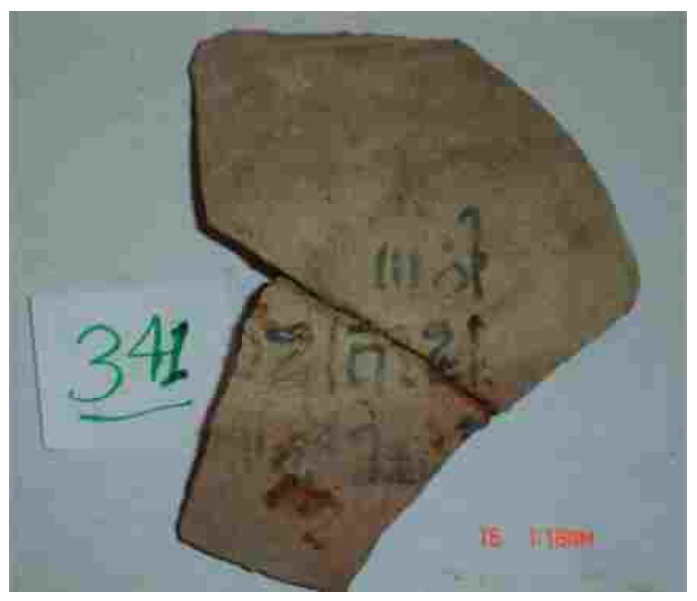

Fig 3: D. NMEC No. 341

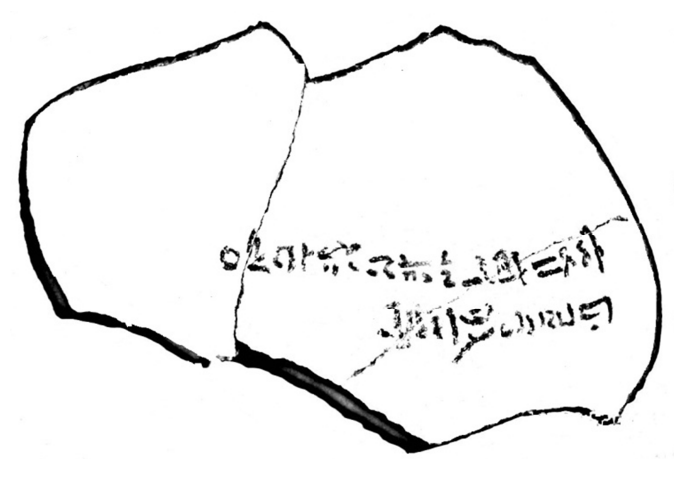

Fig 1a: Facsimile D. NMEC No. 437

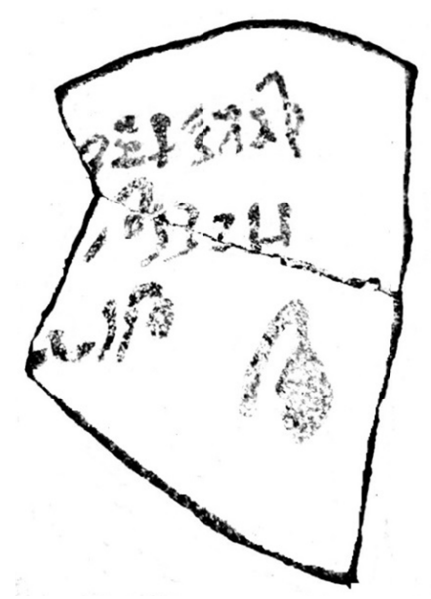

Fig2a: Facsimile D. NMEC No. 332

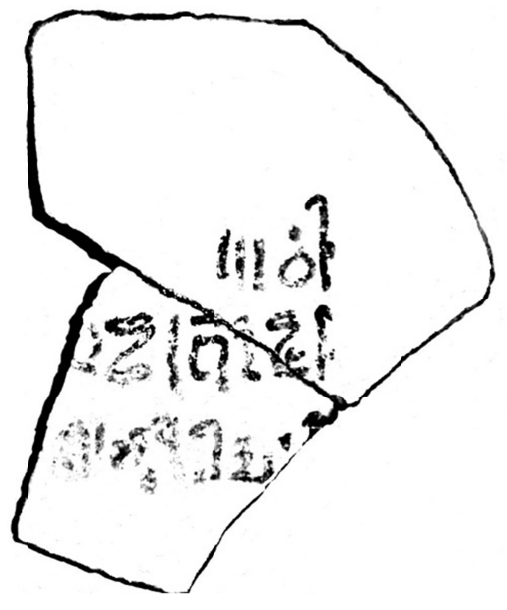

Fig3a: Facsimile D. NMEC 341

\section{Pl.2}






Fig 4: D. NMEC No. 434

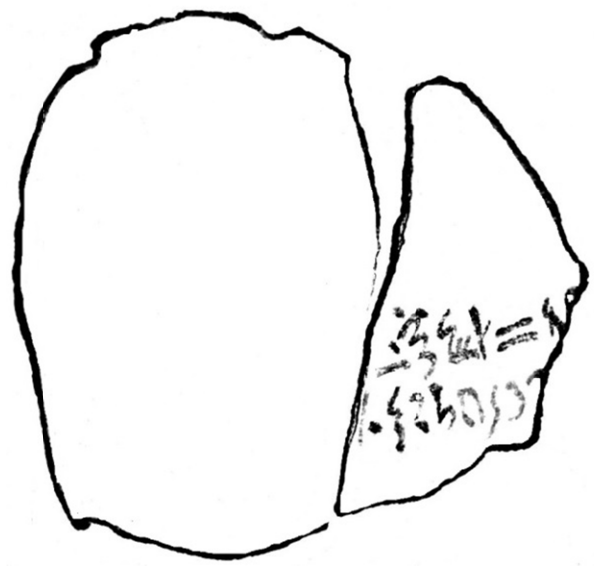

Fig4a: Facsimile D. NMEC No. 434

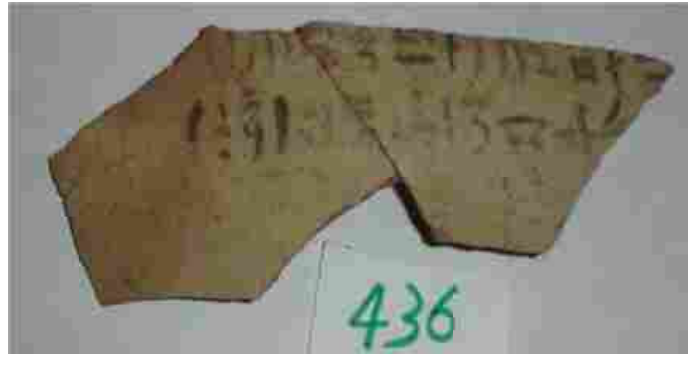

Fig 5: D. NMEC No. 436



Fig 6: D. NMEC No. 429



Fig5a: Facsimile D. NMEC No. 436

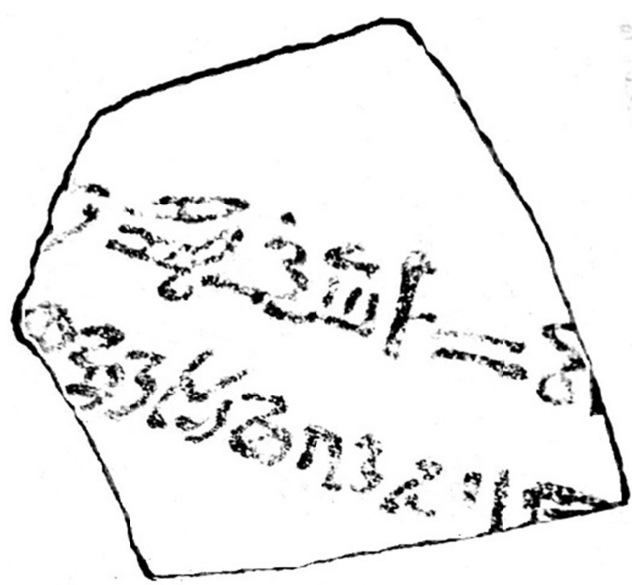

Fig6a: Facsimile D. NMEC No. 429 